\title{
ROMANIA IN THE NEW SECURITY ENVIRONMENT AFTER THE 2021 BRUSSELS SUMMIT
}

\author{
Raul NISTOR, \\ Lieutenant, Master student at the Faculty of Political Science \\ "Global Security Studies" of the West University of Timișoara, Romania. \\ E-mail: n.raul_nistor@yahoo.ro
}

\begin{abstract}
The recent actions of the Russian Federation have raised major concerns among the Euro-Atlantic community. At a time when the security environment we face is becoming increasingly complex, at the NATO Summit in Brussels in 2021, member states reaffirmed their unity, solidarity, cohesion and agreement to open a new chapter in the transatlantic relations. At the same time, NATO remains the foundation of collective security and the essential forum for security consultations and decisions between allies. Romania will also play an extremely important role on NATO's vulnerable south-eastern flank, in the face of the Russian Federation's offensive. Thus, we aim to evaluate the place and role that Romania has as a contributing member of the alliance in ensuring security.
\end{abstract}

Keywords: Russian Federation; NATO; Romania; summit; deterrence and defence; security environment.

\section{Introduction}

The Russian Federation is a revisionist state (Hudson Institute 2015). However, the Soviet Union appeared to be a revisionist power for the first time since World War II in 1990, when President Mikhail Gorbachev's view of post-Cold War Europe's collective security system was not shared by the Euro-Atlantic community. The Soviet Union became dissatisfied, as its opinion was not taken into account, and it could not have a voice in the post-Cold War European security environment that included NATO (North Atlantic Treaty Organization) and the EU (European Union) as main actors (Diyarbakirlioglu 2019, 4). Thus, the Russian Federation seemed to be a potential revisionist state starting with the collapse of the Soviet Union, but it really became one in 2007, with the speech held in Munich (President of Russia 2007), by creating the framework of the "Russian World" (Ukraine Crisis Media Center 2021) and suspending The Conventional Armed Forces in Europe (CFE) Treaty (Radio Free Europe 2007). All this happened after the Colour Revolutions in Georgia in 2003 and Ukraine in 2004 and also after the enlargement of NATO and the EU to Eastern Europe in 2004, through the review of the defence and security policy of the Russian Federation by Vladimir Putin.

In fact, the enlargement of NATO and the EU has posed a threat to the traditional sphere of influence over the former Soviet Union and a challenge to the authoritarian regime in the Russian Federation, as Euro-Atlantic diplomacy promotes values such as democratization, the rule of law and the market economy. These values promoted by NATO and the EU have led to internal conflicts within the former Soviet republics of Georgia and Ukraine. These conflicts simply posed a threat to the Russian Federation, and could eventually spread within the borders of the Russian Federation.

Therefore, with the start of his second term, the Russian president has developed a more assertive foreign and security policy and focused on the dispute with NATO and the EU over 
the former Soviet republics, now independent, and the South Caucasus states. Subsequently, after the NATO Summit in Bucharest in 2008, after Ukraine and Georgia received guarantees for possible NATO integration, the Russian Federation changed its policy of ensuring the integrity of Georgia's territory and decided after the Russian-Georgian War took place in August 2008, to officially recognize the independence of the separatist republics of Abkhazia and South Ossetia (Radio Free Europe 2008). Subsequently, in March 2014, the Russian Federation annexed the Crimean Peninsula and began supporting the secessionist movement in eastern Ukraine. Thus, the Russian Federation has obviously become a revisionist state, making the first annexation of the 21st century, and the Euro-Atlantic community has imposed sanctions to it, but without notable results.

\section{Romania and NATO in the new security environment}

The strategic trends in recent years illustrate the accumulation of a substantial potential to reconfigure the relations between actors with global interests, with direct effects on the stability and predictability of the international system, and the revitalization of global strategic competition confirms the transition to a new security paradigm. This will accentuate the tendency towards a more sustained activity of the states in bilateral plan, with momentary and conjectural interests and alliances, which will affect even more the predictability of the international security environment (Administrația Prezidențială a României 2020, p. 17). The current security environment is characterized by a high degree of dynamism and unpredictability, as well as by the increased globalization of threats and risks, with various manifestations and unlimited potential for geographical spread (Administrația Prezidențială a României 2020, p. 19).

As a state on the eastern flank of NATO and on the eastern border of the European Union, the main vectors for promoting stability and security for Romania are the national capacity and membership to these organizations. Both have proven their ability to effectively meet their objectives of ensuring the security and economic prosperity of the Member States, while demonstrating a strong strategic potential for permanent adaptation to changes in the security environment (Administrația Prezidențială a României 2020, p. 21).

Prior to joining the select club of NATO member states in 2004, Romania sought this goal for a long time, starting with the end of the Cold War. During the accession process, the former Romanian Chief of Defence, General Constantin Degeratu, stated "it is fair to say that no state has led a more aggressive NATO accession campaign than Romania. As Romania cannot claim leadership values in terms of democratization and economic reforms, it has highlighted its strategic location (Puri, n.d., p. 1)."

A decade after Romania joined NATO in March 2014, to the surprise of the international community, the Russian Federation annexed Crimea, violating a whole set of fundamental principles of international law and other treaties that guarantee territorial integrity, inviolability of borders and security to Ukraine (Merezhko 2015). The attitude and actions of the Russian Federation, in violation of the rules of international law, generate the perpetuation and expansion of differences with some Western states and NATO, constituting serious obstacles in identifying viable solutions to ensure stability, predictability and security (Administrația Prezidențială a României 2020, p. 17).

Due to the bringing back to the forefront of Romania as a state bordering the Black Sea, by accepting it in the alliance, NATO expanded its opening to the Black Sea, at the same time Romania becoming part of the south-eastern flank of NATO. Also, the conflict in eastern Ukraine triggered a sharp deterioration in relations between the Russian Federation and the West, but from Romania's perspective, the presence of a regional hegemony of the Russian Federation meant a permanent concern. Thus, the constant actions of the Russian Federation to 
STRATEGIES XXI International Scientific Conference

The Complex and Dynamic Nature of the Security Environment

strengthen its offensive military capabilities in the Black Sea and to create a system of regional interdiction and restriction of access. This will ensure control over the Pontic basin and counterbalance the development of Allied military capabilities on the eastern flank of the NATO. It demands a consolidated national defence position and the continuation of Romania's active attitude in order to consolidate the allied posture of deterrence and defence in the region (Administrația Prezidențială a României 2020, p. 22).

By bringing back to the fore the objective of discouraging the Russian Federation, NATO has really come close to the concerns of its members on the south-eastern flank, including Romania. Romania's geography and history reflect the fact that it must always pay special attention and concern to a dominant and revisionist Russian Federation. Thus, according to Robert D. Kaplan the experience of the communist period as a repressive regime, determined Romania to deeply desire its integration in Western formats such as the EU and NATO. Romania and NATO's objectives of discouraging the Russian Federation converge, as well as Romania's national security calculations, namely to counterbalance the military power of the Russian Federation in the Black Sea, on the same side of the barricade, together with the United States of America (USA) and with Western European states. Therefore, for Romania, the Black Sea region represents an area of maximum strategic interest (Administrația Prezidențială a României 2020, p. 21).

Thus, the potential for escalating tensions in the region, amid the strengthening of the offensive position and the aggressiveness of the Russian Federation in recent years and the improvement of the hybrid instruments it uses, is a major security concern in the national context. From this perspective, strengthening the Alliance's deterrence and defence posture, especially on its eastern flank, through a united north-south approach, enhancing the EU's capacity to act together and the US commitment to the security of the Black Sea region are key elements and sustainable solutions to ensure regional stability. For Romania, it remains a priority to reconfirm the relevance of the Black Sea, with strategic importance in the regional security configuration. That is why, in a dynamic security environment with a high degree of unpredictability, adapting the narrative used to maintain and increase the US, NATO and EU attention on the strategic importance of the Black Sea is a permanent and important process for the country (Administrația Prezidențială a României 2020, p. 22).

\section{Romania's objectives for the 2021 Brussels Summit}

In terms of defence and national security, the Supreme Council of National Defence (CSAT) is the authority responsible for these activities. Procedurally, before the NATO Summit takes place, NATO staff sends a draft of the final statement to the Ministry of Foreign Affairs. Subsequently, the Ministry of Foreign Affairs redistributes this document to state institutions that are part of the CSAT (Presidential Adviser for National Security, Minister of Defence, Minister of Internal Affairs, Minister of Foreign Affairs, Minister of Justice, Minister of Economy, Minister of Entrepreneurship and Tourism, Minister of Finance, Director of the Romanian Intelligence Service, Director of the Foreign Intelligence Service, and Chief of Defence) (Consiliul Suprem de Apărare a Țării 2002). In the first phase, these state institutions evaluate, analyse and make proposals, and after that, CSAT verifies and establishes the main objectives that Romania must support and achieve during the summit.

Therefore, in April, during the CSAT meeting organized in the context of the accumulation of Russian Federation troops on the eastern border of Ukraine, the security situation in the Black Sea region was analysed. In addition, during the meeting of the CSAT, it was decided that, on the NATO line, Romania will continue to promote the steps meant to 
lead to the further consolidation of the allied position in Romania and in the region (Consiliul Suprem de Apărare a Țării 2021).

Subsequently, at the special meeting of the Foreign Ministers of NATO countries, held in video-conference format, whose main objective was the preparation of the NATO Summit on June 14, the Romanian Minister of Foreign Affairs, Bogdan Aurescu, pleaded for the consolidation of the NATO deterrent position in the south of the Eastern Flank and for a massive increase in the Allied presence on the Black Sea. In addition, he called for increased support for NATO partners. Bogdan Aurescu stressed that the measures are necessary in the current context of security in the East, which is marked by Russia's recent actions in the region, including those related to Ukraine, and against the background of its military consolidation in the Black Sea and support for Belarus (Bolocan 2021).

Another important event, which had the role of preparing the ground for the negotiations for the NATO Summit in June, is the B9 Summit in Bucharest in May. The Bucharest Format (B9) is an initiative launched by the President of Romania, Klaus Iohannis, and the President of the Republic of Poland, Andrzej Duda, in which NATO member states on the Eastern Flank of the Alliance take part: Bulgaria, Czech Republic, Estonia, Latvia, Lithuania, Poland, Romania, Slovakia and Hungary (Lupitu May 11, 2021). Romanian President Klaus Iohannis announced at the end of the Summit in a joint press conference with his Polish counterpart, Andrzej Duda, that: "The worrying security situation in the Black Sea has shown us that we must remain vigilant. Therefore, NATO must continue to strengthen its position of deterrence and defence, especially on the Eastern Flank, in a unified and coherent manner, from the Baltic Sea to the Black Sea. That is why I pleaded - including in the discussion with President Biden - for an increase in the Allied military presence, including the USA, in Romania and in the south of the Eastern Flank" (Lupitu May 16, 2021).

Therefore, a priority of Romania's objectives at the NATO Summit in June also seemed to be the attempt to correct the inequality manifested by NATO's defence and deterrence strategy between the north and south of NATO's eastern flank.

\section{Romania's results at the NATO Summit in Brussels}

As I mentioned before, the Black Sea became a hot sea after 2014, when Russia annexed Crimea, supplemented the military arsenal in Sevastopol and started the conflict in Donbas. New battleships were brought to Novorossiysk and Crimea; missiles were mounted that could reach the Romanian shore of the sea or target the Bosphorus.

Worryingly, the Euxinus Pontus has become a large ammunition and weapons depot, a dangerous place where territories can be snatched from what Russia calls its close neighbourhood, so spaces that were part of the Soviet Union until 1991. Ukraine is the first to be targeted, after Abkhazia and South Ossetia were taken from Georgia and Transnistria from the Republic of Moldova. Moscow sent 100,000 soldiers and fighting vehicles to Ukraine's eastern border two months ago, trying to prove once again that it will not allow the country to join the West.

In this context, Romania managed to impose in the final document of the NATO summit in Brussels a series of extremely important issues in the economy of its national security and the security of the eastern flank of NATO and the EU.

Firstly, the strengthening of the NATO's deterrence and defence posture. That is, the presence of NATO troops in the region, in the context of threats from Russia, generously cited in the document. The credible and effective stance invoked in defence and deterrence, especially on the Eastern Flank, means sufficient capabilities and troops to deal with any threat at any time. In addition, the Black Sea region is a region of strategic importance - based on the 
STRATEGIES XXI International Scientific Conference

The Complex and Dynamic Nature of the Security Environment

wealth of mentions made in the document - while the document itself notes that, the security situation on the Black Sea remains worrying (Chifu 2021).

The Alliance is already present in Romania in key points. The South-East Multinational Brigade from Craiova has the mission to provide the training framework for subordinate and affiliated structures, as well as the command and control of a NATO operation type Article 5 Collective Defence, to contribute to the territorial and population security on the Southeast Flank of the Alliance (NATO 2018). The Headquarters Multinational Corps Southeast in Sibiu and the Headquarters Multinational Division Southeast in Bucharest, destined for the Land Forces, represent Romania's substantial contribution to consolidating a credible posture of defence and deterrence on the eastern flank (Agerpress 2020).

The military base in Kogălniceanu hosts several hundred American soldiers and NATO pilots involved in the air police mission over the Black Sea and has the capacity to facilitate the transport of 2,000 soldiers and 3,000 tons of materials per day. The Ministry of Defence will invest 400 million euros for the expansion and modernization of this military base on the seafront for the safe and optimal operation of a squadron of multi-role aircraft, for defensive or offensive operations (Chirileasa 2021).

The Deveselu military base hosts the NATO anti-missile shield: an anti-ballistic radar equipped with 24 interceptor missiles. The system is operated and protected by 500 Romanian soldiers and civilians and 250 American soldiers. The air base at Câmpia Turzii, where the Americans promised to invest 130 million dollars to become a strategic point of the air operations carried out by the United States on the eastern flank of NATO.

The alliance is also present in Romania in pursuit of other strategic objectives. The NATO Center of Excellence in Oradea has trained in the over 10 years of activity about 1500 specialists in the field of intelligence and is the main provider of HUMINT expertise (intelligence from human sources) within the NATO military intelligence services. EuroAtlantic Centre for Resilience, where 70 specialists and their cabinets will work, especially diplomats, civil servants and military along with Romanian or foreign experts.

Secondly, NATO puts more emphasis on its support for Moldova's integrity, democratic reforms and defence assistance. This reference is another success of Romania at the NATO summit in Brussels. The alliance calls on Russia to withdraw its troops forcibly stationed in territories belonging to Georgia, Ukraine and the Republic of Moldova and informs it that NATO will not return to normal relations with Moscow until it complies with its international obligations and demonstrates that implements international law (NATO 2021).

Finally, another key point supported by Romania is the reference, in the text published at the end of the summit, to the importance of the Euro-Atlantic Centre for Resilience recently inaugurated in Bucharest. With the help of this Centre, Romania wants to become a pole of excellence and a provider of expertise for the member states of NATO and the European Union, as President Klaus Iohannis said (NATO 2021).

\section{Conclusions}

Romania has struggled for years to convince the United States and NATO that it is a predictable and trustful partner and that the various misalignments/delays have been just road accidents. The Strategic Partnership with the United States and the major military investments made by the Americans in Romania determined Bucharest to be on Washington's side on every occasion. This includes NATO summits, where Western European states may have different views, suggesting, for example, more sovereignty and a partnership, not protectorate in the relationship with the USA. 
Therefore, Romania represents an extremely important actor and ally for the eastern flank of NATO, which has adopted an active position in this period marked by tensions in the region, after the events of 2014. However, Romania still has a lot of work to do in order to be able to impose and promote its concerns about the security of the Black Sea region. The Russian Federation is a permanent concern for Romanian national security. Unfortunately, we appreciate that NATO does not assess these concerns of Romania at the same level, at the expense of other priorities of the alliance.

This paper has evaluated Romania's objectives at the NATO Summit in Brussels in 2021 and the wins of the efforts to convince the other NATO members regarding the importance of these objectives. In short, we recall the results of the analysis. First, NATO aims to strengthen the deterrence and defence posture. That is, the presence of NATO troops in the region, in the context of threats from Russia, which is generously cited in the final document. Second, after mentioning support for the sovereignty and territorial integrity of Ukraine, Georgia and the Republic of Moldova, the final communiqué notes NATO's very special support for democratic reforms in the Republic of Moldova. Third, the Summit set another goal for Romania, namely the need to increase resilience and maintain NATO's technological advancement. In terms of role, Romania is part of the efforts to increase resilience, by establishing and operationalizing the Euro-Atlantic Centre for Resilience (E-ARC).

However, it is imperative to mention the great failures of this Summit. The inequality in the way of giving importance to the northern part of the eastern flank compared to the southern part, which is clearly superior, has not been resolved even now. The inequality of NATO's security strategy between these two regions still continues and is reflected in the differences between the Enhanced Forward Presence in the Baltic States and Poland in the North and the Tailored Forward Presence in the South. In the text of the final communiqué, the neutral wording of the presence submitted is assumed. Unfortunately, there is no expected formula for a flank, an alliance, a single defence.

\section{BIBLIOGRAPHY:}

Administrația Prezidențială a României. 2020. "Strategia Naţională de Apărare a Ţării pentru Perioada 2020-2024". URL: https://www.presidency.ro/files/userfiles/Documente/ Strategia_Nationala_de_Aparare_a_Tarii_2020_2024.pdf

Agerpress. 2020. "HQ Multinational Corps South-East, established in presence of President Iohannis, DefMin Ciuca, in Cincu". URL: https://www.agerpres.ro/english/ 2020/07/23/hq-multinational-corps-south-east-established-in-presence-of-presidentiohannis-defmin-ciuca-in-cincu--544875

BOLOCAN, Valentin. 2021. "România cere creşterea prezenţei NATO la Marea Neagră: Putin are nevoie de scandal internaţional ca să aibă linişte acasă”. URL: https://adevarul.ro/news/eveniment/romania-cere-cresterea-prezentei-nato-mareaneagra-putin-nevoie-scandal-international-liniste-acasa1_60b7a9135163ec4271b08bd0/index.html

CHIFU, Iulian. 2021. "Summitul NATO de la Bruxelles: Rusia rămâne principala ameninţare a Alianţei". URL: https://adevarul.ro/international/europa/summitul-nato-bruxellesrusia-ramane-principala-amenintare-aliantei-1_60c831cc5163ec427119c6af/index.html

CHIRILEASA, Andrei. 2021." RO Army seeks contractor for EUR $400 \mathrm{mln}$ project to modernize Kogalniceanu military base". Accessed September 28, 2021. https://www.romania-insider.com/kogalniceanu-base-modernization-march-2021 
STRATEGIES XXI International Scientific Conference

The Complex and Dynamic Nature of the Security Environment

Consiliul Suprem de Apărare a Țării. 2002. "Legea nr. 415 din 27 iunie 2002 privind organizarea şi funcţionarea Consiliului Suprem de Apărare a Ţării". URL: https://csat.presidency.ro/ro/prima-pagina/legea-de-organizare

Consiliul Suprem de Apărare a Țării. 2021. "Ședința Consiliului Suprem de Apărare a Țării din 27 aprilie 2021". URL: https://www.presidency.ro/ro/media/sedinta-consiliului-supremde-aparare-a-tarii1619532519

DIYARBAKIRLIOGLU, Kaan. 2019. "Russian and European Union's Quest for the formation of a European security system after the cold war". URL: https://www.tandfonline.com/ doi/pdf/10.1080/23311886.2019.1683928?needAccess=true

Hudson Institute. 2015. "Putin's Russia as a Revisionist Power". URL: https://www.hudson.org/research/11386-putin-s-russia-as-a-revisionist-power

LUPITU, Robert. May 11, 2021. "Joe Biden, la summitul București 9 al aliaților de pe flancul estic: Susțin consolidarea capacității de apărare și descurajare a NATO în faţa acțiunilor competitorilor noștri strategici”. URL: https://www.caleaeuropeana.ro/joe-biden-lasummitul-bucuresti-9-al-aliatilor-de-pe-flancul-estic-sustin-consolidarea-capacitatii-deaparare-si-descurajare-a-nato-in-fata-actiunilor-competitorilor-nostri-strategici/

LUPITU, Robert. May 16, 2021. "Klaus Iohannis l-a invitat pe Joe Biden la București. Ministrul Bogdan Aurescu: Prin participarea la summitul B9, președintele SUA a arătat că are încredere în România”. URL: https://www.caleaeuropeana.ro/klaus-iohannis-l-a-invitatpe-joe-biden-la-bucuresti-ministrul-bogdan-aurescu-prin-participarea-la-summitul-b9presedintele-sua-a-aratat-ca-are-incredere-in-romania/

MEREZHKO, Oleksandr. 2015. "Crimea's Annexation by Russia - Contradictions of the New Russian Doctrine of International Law". URL: https://www.zaoerv.de/75_2015/ 75_2015_1_a_167_194.pdf

NATO. 2018. "Eight Allies join forces in Romania for Exercise SCORPIONS FURY 18". URL: https://www.nato.int/cps/en/natohq/news_160343.htm

NATO. 2021. "Brussels Summit Communiqué. Issued by the Heads of State and Government participating in the meeting of the North Atlantic Council in Brussels 14 June 2021". URL: https://www.nato.int/cps/en/natohq/news_185000.htm

President of Russia. 2007. "Speech and the Following Discussion at the Munich Conference on Security Policy". URL: http://en.kremlin.ru/events/president/transcripts/24034

PURI, Samir. n.d. "Romania: Black Sea Security and NATO's South-Eastern Frontline”. URL: https://www.spf.org/projects/upload/Romania\%2C\%20Black\%20Sea\%20Security\%20a nd\%20NATO\%E2\%80\%99s\%20South-Eastern\%20Frontline\%20\%28Puri\%29.pdf

Radio Free Europe. 2007. "Russia Suspends Participation In CFE Treaty". URL: https://www.rferl.org/a/1079256.html

Radio Free Europe. 2008. "Russia Recognizes Abkhazia, South Ossetia". URL: https://www.rferl.org/a/Russia_Recognizes_Abkhazia_South_Ossetia/1193932.html

Ukraine Crisis Media Center. 2021. "Russkiy Mir” as the Kremlin's Quasi-ideology”. URL: https://uacrisis.org/en/russkiy-mir-as-the-kremlin-s-quasi-ideology 